\title{
Management of Cutworm by Entomopathogenic Nematodes-A Review
}

\author{
Gitanjali Devi*
}

\author{
Department of Nematology, Assam Agricultural University, Jorhat, Assam, India
}

*Corresponding author

\section{A B S T R A C T}

\begin{tabular}{|l|}
\hline Ke y w o r d s \\
Biological control, \\
Cutworm, \\
Entomopathogenic \\
nematodes
\end{tabular}

\section{Introduction}

Cutworms are smooth caterpillars of several moth species (Lepidoptera: Noctuidae).They are polyphagous and ubiquitous insects and have been recorded as serious pests in the world including India (Gulab et al., 2001; Mrowczynski et al., 2003; Napiorkowska and Gawowska, 2004). Several species of cutworms, viz., Agrotis spp. Peridroma saucia, Amathes $c$ - nigrum, Spodoptera frugiperda, S. exigua and S. litorallis cause serious problems to agricultural, vegetable and forage crops. These insects cause considerable damage by cutting seedlings at the ground level thereby reducing the yield .The caterpillars emerging from the eggs grow with several moults until they are full size and then pupate in the ground, moths emerge from those pupae. It may take one month or a year to complete the life-cycle depending on the species involved and the weather. The black cutworm, Agrotis ipsilon (Hufnagel) is a major pest of over 30 economically important agricultural and horticultural crops in many parts of the world, which makes it survive nearly in every agro ecosystem (Rings et al., 1975).Black cutworm larvae vary in size from $3 \mathrm{~mm}$ to $50 \mathrm{~mm}$. They are light gray to almost black in colour and have a greasy appearing texture and coarse granules of various sizes that can be seen on their body covering. Moths are attracted to green vegetation for egg laying. Newly hatched larvae feed on 
weeds or young plants, leaving small irregular holes in the leaves. Larger larvae may notch the stems of seedlings immediately below the soil surface, which can cause plants to wilt and die. They may completely cut through stalks, which can result in severe stand reductions. They usually feed at night or during overcast days. They sometimes drag cut plants under dirt clods or into small holes in the soil to continue their feeding during the daylight hours. More than $80 \%$ of the losses occur after reaching the fourth instar of larvae, which cuts several plants overnight (Abdel-Gawaad and El-Shazli 1971 and Capinera 2001). Crop losses were due to its wide host range including weeds, hidden lifestyle, feeding behavior, prolonged egg laying, and its ability for long-distance migration (Ya-Zhong ,1992; Showers et al., 1993; Capinera,2001).Chemical control used against $A$. ipsilon larvae is often not effective and remains inadequate for the control of this pest because of its larval hiding behavior during the daylight hours and the resistance to most of the chemicals (Capinera, 2001; Takeda, 2008). Moreover, the negative impact of the chemicals has led researchers to search for new control strategies (Laznik and Trdan, 2012).

\section{Management through biological method}

Biological control agents including fly and wasp parasites, disease organisms like granulosis virus, fungi, bacteria and protozoa and predatory beetles reduce cutworm numbers to certain level. But none of them could bring down cutworm population within a short time.

Biological control by entomopathogenic nematodes (EPNs) appears to be one of the sustainable alternatives to manage this pest. An entomopathogenic nematode, Hexamermis arvalis (Nematoda: Mermithidae) is known to parasitize up to $60 \%$ of larvae in the central
USA (Puttler and Thewke, 1971). An ectoparasitic nematode Noctuidonema guyanense parasitized the adult stage of fall armyworm (Rogers et al., 1991). Entomopathogenic nematodes (EPNs) of the genera Steinernema and Heterorhabditis are capable of controlling a variety of economically important insect pests (Klein, 1990; Shapiro-Ilan et al., 2002). The infective juveniles (IJs) of EPNs enter the host insect and release their symbiotic bacteria (Photorhabdus spp. or Xenorhabdus spp.), which cause septicemia leading to the death of the insects within 24-48 hrs. Searching ability of the host, high virulence, ease of culturing, safety to nontarget organism have led to successful integration of these nematodes into pest management programme for the control of soil borne pests especially cutworm (Kaya and Gaugler, 1993; Hussaini 2014; Shapiro-Ilan et al., 2015).

\section{Case studies of Entomopathogenic nematodes}

Many studies have been conducted in order to evaluate the virulence and control potential of entomopathogenic nematodes (EPNs) species or isolates against $A$. ipsilon larvae (Israel et al., 1969; Simons and Guys, 1980; Morris,1985; Capinera et al., 1988; Georgis et al., 1989; Morris et al., 1990; Morris and Converse, 1991; Shamseldean et al., 1994; Baur et al., 1997; Shamseldean and Ismail, 1997; Shapiro et al., 1999; Hussaini et al., 2000a, 2000b, 2001, 2002, 2003， 2005; Mathasoliya et al., 2004; Kunkel et al., 2004; Fetoh et al., 2009; Richmond and Bigelow, 2009; Seal et al., 2010; Ebssa and Koppenhöfer 2011; 2012; Mantoo et al., 2012; Bélair et al., 2013; Khattab and Azazy 2013; Lee et al., 2013; Han et al., 2014; Yan et al., 2014; Goudarzi et al., 2015; Saleh et al., 2015; Hassan et al., 2016; Mahmoud et al., 2016; Mazurkiewicz et al., 2016; Souad, 2016; Vashisth et al., 2018; Yuksel and 
Canhilal, 2018). Control of Agrotis segetum with Steinernema feltiae (Neoplectana bibionis) in lettuce was equivalent to endosulfan, under field conditions (Lossbroek and Theunissen 1985). A. ipsilon has been effectively managed with $S$. carpocapsae on golf course greens. Larvae and pupae of armyworms are very susceptible to entomopathogenic nematodes and can be effectively managed by nematodes (Kaya and Grieve 1982). Chandel et al.,(2009) found that 1000 IJs of Heterorhabditis bacteriophora per $\mathrm{kg}$ soil were found to be sufficient to initiate the infection and kill up to $61.3 \%$ of $5^{\text {th }}$ instar larvae of $A$. segetum after 7 days of exposure. Richter and Fuxa (1990) reported 33-43\% infection of $S$. frugiperda by $S$. carpocapsae in field corn. They also found that spraying of nematodes onto corn ears reduce damage of S. frugiperda up to $71 \%$. Molina-Ochoa et al., (1999) evaluated the susceptibility of $S$. frugiperda to several species of nematodes and found that the $\mathrm{LC}_{50}$ ranged from 1.5 to 20.6 and 3.4 to 37.2 nematodes $/ \mathrm{ml}$ for larvae and prepupae, respectively. They concluded that $S$. carpocapsae All strain, S. riobrave, and $H$. megidis have potential for controlling $S$. frugiperda. Shoeb et al., (2006) investigated the efficacy of $S$. abbasi and H. bacteriophora against the fourth instar larvae of $A$. ipsilon in Petri dishes in the laboratory study at $27 \pm 1$ ${ }^{\circ} \mathrm{C}$. They reported that $H$. bacteriophora caused 49, 53, and $73 \%$ mortality rates, respectively, at 25,50 , and $100 \mathrm{IJ} /$ /larva in the second day after the treatment. Fetoh et $a l .$, (2009) evaluated the effectiveness of $S$. carpocapsae and $H$. bacteriophora against fourth instar $A$. ipsilon larvae at concentrations of 25, 50, $100 \mathrm{IJs} / \mathrm{ml}$ in Petri dish under laboratory conditions. Mortality rates, at the second day after treatment, were found as 70,85 , and $100 \%$ for $S$. carpocapsae and 80,90 , and $100 \%$ for $H$. bacteriophora at concentrations of 25,50 , and $100 \mathrm{IJs} / \mathrm{ml}$, respectively. Unlu et al., (2007), also compared the efficacy of S. weiseri (BEY), S. feltiae (TUR-S3), and S. carpocapsae (TUR) isolated in Turkey against last instar larva of A. segetum. Each nematode species was applied at 10, 25, 50, and 100 IJs per $A$. segetum larva in $10 \mathrm{ml}$ of water. S. weiseri was more effective than S. feltiae (TUR-S3) at 50 and 100 IJs per larva; however, $S$. weiseri was less effective than $S$. carpocapsae. The efficacy of $S$. kraussei was tested on Agrotis segetum larvae at different densities (100, 300, and 500 infective juveniles (IJs) $\mathrm{g}^{-1}$ dry sand) in laboratory conditions at $25{ }^{\circ} \mathrm{C}$. The highest mortality (98\%) was obtained with $500 \mathrm{IJs} \mathrm{g}^{-1}$ dry sand within $7 \mathrm{~d}$ after inoculation (Gokce et al., 2013).

EPNs can provide excellent control of cutworms (Agrotis spp.) in many different field crops, which often exceeds the level of control provided by insecticides. Field application of S.carpocapsae reduced the black cutworm (A.ipsilon) damage by $50 \%$ on maize (Capinera et al., 1988). Levine and Oloumi-Sadeghi(1992) found that a single application of S.carpocapsae reduced the number of cut maize plants by $76-83 \%$ during the 1-10 days after treatment. Yokomizo and Kashio (1996) reported that a single ground spray of S.carpocapsae at 1 billion IJs/ha or two applications of 0.5 billion IJs / ha with an 8 day interval caused 80 and $67 \%$ mortality of turnip moth (Agrotis segetum) larvae, respectively. To be effective, entomopathogenic nematodes must usually be applied to soil at rates of $2.5 \times 10^{9} \mathrm{IJ} / \mathrm{ha}$ or higher (Georgis and Hague, 1991; Georgis et al., 1995; Shapiro-Ilan et al., 2002). In cases where the pest is particularly susceptible or in controlled condition such as in the greenhouse, lower application rates might also be effective. For example, $S$. carpocapsae applied at the relatively low rate of $12.5 \mathrm{IJs} / \mathrm{cm}^{2}$ reduced black cutworm, Agrotis ipsilon (Hufnagel) damage in field 
corn by more than $75 \%$, which was as effective as or more so than the chemical insecticides tested (Levine and OloumiSadeghi, 1992).

In conclusion, soil type, temperatures and moisture are considered as important physical factors influencing nematode mobility, efficacy, reproduction, development and persistence in the field (Kung, 1990). S. carpocapsae, S.abbasi, S.glaseri, H.indica13.3, H.indica 6.71 caused absolute mortality of last instar larvae of Agrotis ipsilon at $25^{\circ} \mathrm{C}$ during $48 \mathrm{~h}$ exposure period (Hussaini et al., 2005). Therefore, their populations normally need to be supplemented with accurate virulent strain to realize high levels of parasitism. Nematodes are applied with irrigation and should be done early in the summer season when larvae are most vulnerable. Entomopathogenic nematodes thus offer an ecofriendly and IPM compatible alternative to chemical insecticides for the management of cutworm.

\section{References}

Abdel-Gawaad, A.A. and El-Shazli, A.Y. Studies on the common cutworm Agrotis ipsilon Rott. I. Life cycle and habits. Z Angew Entomol. 1971; 68:409-412

Baur, M.E., Kaya, H.K. and Tabashnik, B.E. Efficacy of a dehydrated steinernematid nematode against black cutworm (Lepidoptera: Noctuidae) and diamondback moth (Lepidoptera: Plutellidae). J. Econ. Entomol. 1997; 90: 1200-1206.

Bélair, G., Simard, L. and Dionne, J. Canadian entomopathogenic nematode isolates: virulence against black cutworm (Lepidoptera: Noctuidae). Phytoprotection. 2013; 93(1):4346.

Capinera, J.L. Hand book of vegetable pests. Academic Press, New York, 2001;729 pp.

Capinera, J.L., Epsky, N.D., Menout, G.S. and Pelissier, D. Control of black cutworm, Agrotis ipsilon (Lepidoptera: Noctuidae), with entomogenous nematodes (Nematoda:
Steinernematidae, Heterorhabditidae). J.Invertebr.Pathol.1988; 52(3):427-435.

Chandel,Y.S., Kapoor, S. and Kumar, S. Virulence of Heterorhabditis bacteriophora (Poinar) against cutworms, Agrotis segetum (Denis and Schiff). J Biol Control. 2009; 23(4): 409-415.

Ebssa, L. and Koppenhofer, A.M. Efficacy and persistence of entomopathogenic nematodes for black cutworm control in turfgrass. Biocontrol Sci. Technol. 2011; 21: 779-796.

Ebssa, L. and Koppenhöfer, A. M. Entomopathogenic nematodes for the management of Agrotis ipsilon: effect of instar, nematode species and nematode production method. Pest Manag. Sci. 2012; 68 (6): 947-957.

Fetoh, B.A., Amani, S.K. and Thoraia, F.K.E. Combined effect of entomopathogenic nematodes and biopesticides to control the greasy cutworm, Agrotis ipsilon (Hufn.) in the strawberry fields. Egypt Acad J Biology Sci. 2009; 2(1):227-236.

Georgis, R. and Hague, N.G.M. Nematodes as biological insecticides. Pestic Outlook. 1991; 3: 29-32.

Georgis, R., Dunlop, D.B. and Grewal, P.S. Formulation of entomopathogenic nematodes. In: Biorational Pest Control Agents: Formulation and Delivery. (Eds. Hall, F.R., Barry, J.W.), American Chemical Society, Washington, DC, 1995; 197-205 pp.

Georgis, R., Wojciech, W.F. and Shetlar, D.J. Use of Steinernema feltiae in a bait for the control of black cutworms (Agrotis ipsilon) and tawny mole crickets (Scapteriscus vicinus). Fla. Entomol. 1989; 72: 203-204.

Gokce, C., Yilmaz, H., Erbas, Z., Demirbag, Z. and Demir, I. First record of Steinernema kraussei (Rhabditida: Steinernematidae) from Turkey and its virulence against Agrotis segetum (Lepidoptera: Noctuidae). $J$. Nematol., 2013; 45(4): 253-259.

Goudarzi, M., Moosavi, M.R. and Asadi, R. Effects of entomopathogenic nematodes, Heterorhabditis bacteriophora (Poinar) and Steinernema carpocapsae (Weiser), in biological control of Agrotis segetum (Denis \& Schiffermüller) (Lepidoptera: Noctuidae). Turk. Entomol. Derg., 2015; 39(3): 239-250.

Gulab, R., Mishra, S. S. and Dhamayanthi, K. P. 
M. Relative susceptibility of advanced hybrids and promising cultivars of potato, Solanum tuberosum L. to greasy cutworm, Agrotis ipsilon (Hufn.) in North-eastern plains. $J$. Entomol. Res. Soc. 2001; 25: 183-187.

Han, R., Wang, X., Qiu, X., Yan, X. Utilisation of entomopathogenic nematodes, Heterorhabditis spp. and Steinernema spp., for the control of Agrotis ipsilon (Lepidoptera, Noctuidae) in China. Nematology, 2014; 16(1): 31-40.

Hassan, H.A., Shairra, S.A., Ibrahim, S.S. Virulence of entomopathogenic nematodes Steinernema glaseri and Heterorhabditis bacteriophora Poinar (HP88 strain) against the black cutworm, Agrotis ipsilon. Egypt. Acad. J. Biolog. Sci., 2016; 9(1): 33-48.

Hussaini, S. Potential of entomopathogenic nematodes in integrated pest management. In: Integrated Pest Management Reviews. Springer Verlag. 2014; 193-223 pp.

Hussaini, S.S., Shakeela, V. and Dar, M.H. Influence of temperature on infectivity of entomopathogenic nematodes against black cutworm, Agrotis ipsilon (Hufnagel) and greater wax moth, Galleria mellonella (Linnaeus) larvae. J Biol Control, 2005. 19(1): 51-58.

Hussaini, S.S., Singh, S.P., Parthasarathy, R. and Shakeela, V. Virulence of native entomopathogenic nematodes against black cutworms, Agrotis ipsilon (Hufnagel) and A. segetum (Noctuidae: Lepidoptera). Indian $J$ Nematol., 2000a; 30(1): 86-110.

Hussaini, S.S., Singh, S.P., Parthasarathy, R.and Shakeela, V. Infectivity of native populations of Steinernema spp. and Heterorhabditis indica in sand and sandy loam soil columns against Agrotis ipsilon (Hufnagel). Annals of Plant Protection Sciences, 2000b; 8(2): 200205.

Hussaini, S.S., Singh, S.P., Parthasarathy, R., Shakeela, V. Determination of dosage levels of Steinernema bicornutum and Heterorhabditis indica for in vitro use against Agrotis ipsilon Hufnagel. Entomon, 2002; 27(3): 313-317.

Hussaini, S.S., Singh, S.P., Parthasarathy, R.and Shakeela, V. Comparison of bioassays to measure the infectivity of some isolates of entomopathogenic nematodes against Agrotis ipsilon (Hufnagel) and A. segetum (Schiff).
Current Nematology, 2001; 12(1-2): 63-68.

Hussaini, S.S., Singh, S.P., Shakeela, V. Variable efficacy of different formulations of entomopathogenic nematodes against black cutworm Agrotis ipsilon (Hufnagel) larvae. Biological control of lepidopteran pests Proceedings of the Symposium of Biological Control of Lepidopteran Pests, July 17-18, 2002, Bangalore, India. 2003. Pp. 193-197.

Israel, P., Rao, Y.R.V.J., Rao, P.S.P. and Varma, A. Control of paddy cutworms by DD 136, a parasitic nematodes. Curr. Sci. 1969; 38: 390391.

Kaya, H.K. and Grieve, B.J. The nematode Neoplectana carpocapsae and the beet armyworm Spodoptera exigua: Infectivity of prepupae and pupae in soil and of adults during emergence from soil. J. Invertebr. Pathol., 1982; 39: 192-197.

Kaya, H.K. and Gaugler, R. Entomopathogenic nematodes. Аnnu. Rev. Entomol. 1993; 38:181-206.

Khattab, M. and Azazy, A.M. Efficacy of entomopathogenic nematodes as bait formulations for controlling the black cutworm Agrotis ipsilon (Hufnagel) (Lepidoptera: Noctuidae). Egypt J Biol Pest Co. 2013 ; 23(2): 255

Klein, M.G. Efficacy against soil inhabiting insect pests. In: Entomopathogenic nematodes in biological control (Eds. Gaugler R and Kaya HK.). Boca Raton, Florida, CRC Press. 1990; 195-214 pp.

Kung, S.P. Abiotic factors affecting the persistence of two entomopathogenic nematodes. Steinernema carpocapsae. and Steinernema glaseri (Nematoda: Steinernematidae) in the soil. Dissertation Abstracts International. $B, \quad$ Sciences and Engineering, 1990; 51(4): 1620.

Kunkel, B.A., Grewal, P.S. and Quigley, M.F.A mechanism of acquired resistance against an entomopathogenic nematode by Agrotis ipsilon feeding on perennial ryegrass harboring a fungal endophyte. Biol Control. 2004; 29: 100-108.

Laznik, Z. and Trdan, S.Entomopathogenic nematodes (Nematoda: Rhabditida) in Slovenia: from tabula rasa to implementation into crop production systems. In: Insecticides Advances in Integrated Pest Management. 
(Ed. Perveen F). 2012.

Lee, D., Lee, C.M., Lee, S.M. and Potter, D.A. Biological control of black cutworm, Agrotis ipsilon (Lepidoptera: Noctuidae) with Korean entomopathogenic nematode, Steinernema carpocapsae GSN1 strain (Rhabditida: Steinernematidae) in turfgrasses. Weed Turf. Sci. 2013; 4(1): 58-64.

Levine, E. and Oloumi-Sadeghi, H.Field evaluation of Steinernema carpocapsae (Rhabditida: Steinernematidae) against the black cutworm (Lepidoptera: Noctuidae) larvae in Weld corn. J. Entomol. Sci., 1992; 27, 427-435.

Lossbroek, T. G., and Theunissen, J. The entomogenous nematode Neoplectana bibionis as a biological control agent of Agrotis segetum in lettuce. Entomologia Experimentalis et Applicata, 1985; 39: 261264.

Mahmoud, M.F., Mahfouz, H.M. and KM, M. Compatibility of entomopathogenic nematodes with neonicotinoids and Azadirachtin insecticides for controlling the black cutworm, Agrotis ipsilon (Hufnagel) in canola plants. IJRES, 2016; 2(1): 11-18.

Mantoo, M.A., Zaki, F.A. and Waliullah, M.I.S. Virulence of Kashmir isolate of EPN Heterorhabditis bacteriophora (Nematoda:Heterorhabditidae) against black cutworm (Agrotis ipsilon). SKUAST Journal of Research. 2012; 14(1\&2): 67-72.

Mathasoliya, J.B., Maghodia, A.B. and Vyas, R.V. Efficacy of Steinernema riobrave against Agrotis ipsilon Hufnagel (Lepidoptera: Noctuidae) on potato. Indian $J$ Nematol., 2004; 34(2): 177-179.

Mazurkiewicz, A., Jakubowska, M., Tumialis, D. and Pezowicz, E. Sensitivity of Agrotis exclamationis L. (Lepidoptera: Noctuidae) larvae to native strains of entomopathogenic nematodes. Acta Scientiarum Polonorum. Hortorum Cultus., 2016; 15(2):121-127.

Molina-Ochoa, J., Lezama-Gutierrez, R., Hamm, J.J., Wiseman, R.R. and Lopez-Edwards, M. Integrated control of fall armyworm (Lepidoptera: Noctuidae) using resistant plants and entomopathogenic nematodes (Rhabditida: Steinernematidae). Fla Entomol., 1999; 82(2):263-271.

Morris, O.N., Converse, V. and Harding, J.
Virulence of entomopathogenic nematodebacteria complexes for larvae of noctuids, a geometrid, and a pyralid. Can Entomol. 1990; 122: 309-319.

Morris,O.N. and Converse,V.Effectiveness of steinernematid and heterorhabditid nematodes against noctuid, pyralid, geometrid species in soil.Can.Entomol., 1991;123:55-61.

Morris,O.N.Susceptibility of 31 species of agricultural insect pests to the entomogenous nematodes Steinernema feltiae and Heterorhabditis bacteriophora. Can Entomol. 1985; 117(4): 401-407

Mrowczynski, M., Wachowiak, H. and Boron, M. Cutworm - a dangerous pest in the autumn of 2003. Ochrana Roslin, 2003; 47: 24-26.

Napiorkowska, K. J. and Gawowska, J. Increase of harmfulness of caterpillars (Hadeninae and Noctuinae, Lepidoptera: Noctuidae) on cabbage and other cole crops. Progress in Plant Protection, 2004; 44: 978-980.

Puttler, B. and Thewke, S.E. Field and laboratory observations of Hexamermis arvalis (Nematoda: Mermithidae) a parasite of cutworms. Ann Entomol Soc Am. 1971; 64(5): 1102-1106.

Richmond, D.S., and Bigelow, C.A. Variation in endophyte plant associations influence black cutworm (Lepidoptera: Noctuidae) performance and susceptibility to the parasitic nematode Steinernema carpocapsae. Environ. Entomol. 2009; 38: 996-1004.

Richter, A.R. and Fuxa, J.R. Effect of Steinernema feltiae on Spodoptera frugipera and Heliothis zea (Lepidoptera: Noctuidae) in corn. J. Econ. Entomol. 1990; 83: 1286-1291.

Rings, R.W., Arnold, F.J. and Johnson, B.A. Host range of the black cutworm on vegetables: a bibliography. ESA Bull, 1975; 21(4): 229-234

Rogers, C.E., Simmons, A.M. and Marti, O.G. Noctuidonema guyanense: An ectoparasitic nematode of fall armyworm adults in the tropical America. Fla Entomol. 1991; 74(2): 246-257.

Saleh, M.M.E., Hussein, M.A., Hafez, G.A., Hussein, M.A., Salem, H.A. and Metwally, H.M.S. Foliar application of entomopathogenic nematodes for controlling Spodoptera littoralis and Agrotis ipsilon (Lepidoptera: Noctuidae) on corn plants. Adv. Appl. Agric. Sci. 2015; 3: 51-61. 
Seal, D.R., Jha, V.K. and Liu, T.X. Potential of various strains of entomopathogenic nematodes in combination with insecticides for suppression of black cutworm, Agrotis ipsilon (Lepidoptera: Noctuidae). Ann $\mathrm{Pl}$ Protec Sci., 2010; 18(2):293-300.

Shamseldean, M.M., Abd El-Gawad, M.M. and El-Bishry, M.H. Comparative infectivity of native heterorhabitid nematodes and the potential use of one isolate against some economically important pests in Egypt. Egypt J Biol Pest Cont., 1994; 4(2): 133-139

Shamseldean, M.M.M. and Ismail, AA. Effect of the nematode Heterorhabditis bacteriophora and the bacterium Bacillus thuringiensis as integrated biocontrol agents of the black cutworm. Anzeiger Schadlingskde., Pflanzenschutz, Umweltschutz. 1997; 70(4): 77-79.

Shapiro, D.I., Obrycki, J.J., Lewis, L.C., Abbas, M.The effects of fertilizers on black cutworm, Agrotis ipsilon, (Lepidoptera: Noctuidae) suppression by Steinernema carpocapsae. J. Nematol., 1999; 31: 690-693.

Shapiro-Ilan, D.I., Gouge, D.H., Koppenhöfer, A.M. Factors affecting commercial success: case studies in cotton, turf and citrus. In: Entomopathogenic Nematology. (Ed.Gaugler,R.), CABI Publishing, Wallingford, UK, 2002; 333-356 pp.

Shoeb, M.A., Atalla, F.A. and Matar, A.M. Pathogenicity of the entomopathogenic nematodes; Steinernema abbasi and Heterorhabditis bacteriophora to certain economic insect pests. Egypt J Biol Pest Co., 2006;16(1/2):99-102.

Showers, W.B., Keaster, A.J., Raulston, J.R., Hendrix, W.H., Derrick, M.E., McCorcle, M.D. and Goodenough, J.L. Mechanism of southward migration of a noctuid moth [Agrotis ipsilon (Hufnagel)]: a complete migrant. Ecology, 1993; 74(8): 2303-2314

Simons, W.R. and Guys, P. Control of insects with nematodes. In: Integrated control of insect pests in the Netherlands. (Ed.
A.K.Minks), Centre for Agricultural Publishing and Documentations. Wageningen, Netherlands. 1980; 275-278pp

Souad, S. Virulence of Entomopathogenic Nematodes Steinernema glaseri and Heterorhabditis bacteriophora Poinar (HP88 strain) against the black cutworm, Agrotis ipsilon. Egypt. Acad. J. Biolog. Sci., 2016; 9(1): 33- 48

Takeda, M. Current research of pest insects of vegetables in last decade. Annual Rep Kansai Plant Protect, 2008. 50: 39-44.

Unlu, I.O., Ehlers, R.U. and Susurluk, I.A. Additional data and first record of entomopathogenic nematode Steinernema weiseri from Turkey. Nematology, 2007; 9: 739-741.

Vashisth, S., Chandel, Y.S. and Chandel, R.S. Biological control potential of North West Himalayan strains of heterorhabditid nematodes against the turnip moth, Agrotis segetum (Denis \& Schiffermuller) (Lepidoptera: Noctuidae). Egypt J Biol Pest Co. 2018; 28: 37.

Yan, X., Wang, X., Han, R. and Qiu, X. Utilisation of entomopathogenic nematodes, Heterorhabditis spp. and Steinernema spp., for the control of Agrotis ipsilon (Lepidoptera, Noctuidae) in China. Nematology, 2014; 16: 31-40.

Ya-Zhong J. The flight activity of the black cutworm moth. Acta Entomol Sin, 1992; 1: 009.

Yokomizo, K. and Kashio, T. Application of an entomogenous nematode, Steinernema carpocapsae, for control of the cutworm, Agrotis segetum, in carrot fields. Proceedings of the Association for Plant Protection of Kyushu, 1996; 42: 89-92.

Yuksel, E. and Canhilal, R.Evaluation of local isolates of entomopathogenic nematodes for the management of black cutworm, Agrotis ipsilon Hufnagel (Lepidoptera: Noctuidae). Egypt J Biol. Pest Co.2018; 28: 82.

\section{How to cite this article:}

Gitanjali Devi. 2020. Management of Cutworm by Entomopathogenic Nematodes-A Review. Int.J.Curr.Microbiol.App.Sci. 9(06): 2520-2526. doi: https://doi.org/10.20546/ijcmas.2020.906.306 